\title{
Not a Second Time? John Lennon's Aeolian Cadence Reconsidered
}

\section{Wouter Capitain}

To cite this article: Wouter Capitain (2018) Not a Second Time? John Lennon's Aeolian Cadence Reconsidered, Rock Music Studies, 5:2, 142-160, DOI: 10.1080/19401159.2018.1484613

To link to this article: https://doi.org/10.1080/19401159.2018.1484613
(C) 2018 The Author(s). Published by Informa UK Limited, trading as Taylor \& Francis Group.
曲 Published online: 10 Sep 2018.

Submit your article to this journal

Џلll Article views: 170

View Crossmark data $\nearrow$ 


\title{
Not a Second Time? John Lennon's Aeolian Cadence Reconsidered
}

\author{
Wouter Capitain
}

University of Amsterdam and Utrecht University, The Netherlands

\begin{abstract}
In 1963 William Mann coined the term "aeolian cadence" to describe a harmonic progression in the song "Not a Second Time" by the Beatles. This term has caused confusion ever since. In this article, I discuss why Mann might have used this confusing phrase and how it relates to this song by John Lennon. I will argue that, in the debate that ensued from Mann's observations, his commentators were primarily preoccupied with terminology and definitions but forgot to listen to Lennon. More specifically, I argue that, if the interplay between the music and lyrics is considered, the famous cadence in "Not a Second Time" can best be interpreted as "deceptive."
\end{abstract}

\section{Introduction}

In the famous Playboy interview conducted by David Sheff in September 1980, John Lennon discussed the impact of a single brief review about the Beatles, which was published roughly one year after their British breakthrough in early 1963. As Lennon recalled: "It was only after some guy in the London Times said there were aeolian cadences in 'It Won't Be Long' that the middle classes started listening to it - because somebody put a tag on it" (Golson 78). The guy Lennon referred to was William S. Mann, and the song in which he identified an aeolian cadence was actually not "It Won't Be Long" but a different composition by Lennon, "Not a Second Time."

The review "What Songs the Beatles Sang" in The Times from 27 December 1963 was published without a byline, except "From Our Music Critic," but was soon attributed to Mann, chief music critic of The Times from 1960 to 1982. Mann was classically educated in piano and composition, and his writings usually concentrated exclusively on European classical music. In this end-of-year review, however, he surprised his readers with the claim that the "outstanding English composers of 1963 must seem to have been John Lennon and Paul McCartney" (Mann, "What Songs the Beatles Sang" 4). ${ }^{1}$ Although this opening statement might have raised a few eyebrows among the readers of The Times, it was not the first time that the Beatles received praise from British higher-class circles. For example, Queen Elizabeth the Queen Mother, who 
attended their performance at the Royal Variety Show on 4 November 1963, allegedly proclaimed: "They are so fresh and vital. I simply adore them" (Schaffner 22). ${ }^{2}$ But what distinguished Mann's review is his adoration specifically for the Beatles' music rather than their stage appearance. Indeed, Mann approached Lennon and McCartney as composers instead of teen idols, and he emphasized that he was "not concerned here with the social phenomenon of Beatlemania, [...] but with the musical phenomenon" ("What Songs the Beatles Sang" 4). After briefly reviewing the musical qualities of several songs from their first two albums, Please Please Me (March 1963) and With the Beatles (November 1963), Mann concluded that the Beatles "have brought a distinctive and exhilarating flavour into a genre of music that was in danger of ceasing to be music at all" ("What Songs the Beatles Sang" 4). As Lennon remembered years later in the Playboy interview, Mann's approval of their musical qualities "started the whole intellectual bit about the Beatles" (Golson 152).

Lennon perhaps overstated the impact of Mann's review, yet since its initial publication this short text has attracted remarkable attention, with many commentators emphasizing the significance of the review for the intellectual reception of the Beatles. For example, Walter Everett observes that as a result of Mann's article, their music "was suddenly attracting critical acclaim from the highbrows" (The Beatles as Musicians 192), and Bill Harry also claims that Mann's prestigious feature "did much to enhance the Beatles' reputation as serious musicians" (713). Whereas Everett and Harry note the impact of Mann's review in general, other authors underline its impact specifically within musicological circles. For example, Michael Bach discusses Mann's text as the first attempt to describe popular music through academic terminology (102), and Dominic Pedler asserts that Mann "rightly takes his place as The Father Of Beatles Musicology" (146). By contrast, Wilfred Mellers remembered that the first musically literate piece about the Beatles "was greeted with hoots of mirth both from the Beatles themselves and from their hostile critics" (15), and Richard Taruskin similarly argues that Mann's article "was greeted mainly with chuckles and filed away as an eccentricity" (319). David Brackett makes a similar observation, albeit with more nuance, when explaining that although "some of their most dedicated fans may dispute the appropriateness of this terminology for the Beatles' music, the fact that a music critic for the London Times would deign to analyse the music in this way (and approvingly at that) was significant and a harbinger of things to come" ("Beatles" 171). Although these commentators differ in their perception of the manner and degree of Mann's impact, it is clear that throughout the decades Mann continues to impress his readers.

Mann's identification of an "aeolian cadence" in "Not a Second Time," as alluded to by Lennon in the Playboy interview, is undoubtedly his most frequently cited phrase. Mann coined this phrase about halfway into his 1963 review, while praising the harmonic qualities of several early songs by the Beatles. According to Mann:

But harmonic interest is typical of their quicker songs too, and one gets the impression that they think simultaneously of harmony and melody, so firmly are the major tonic sevenths and ninths built into their tunes, and the flat submediant key switches, so natural is the Aeolian cadence at the end of "Not a second time" (the chord progression which ends Mahler's Song of the Earth). ("What Songs the Beatles Sang" 4) 
Following Taruskin, we might regard Mann's reference to Mahler "only as an inventory of the critic's own musical tastes and memory" (319), yet the "aeolian cadence" cannot easily be brushed aside as an "eccentricity." After all, Mann's readers might wonder: What exactly did he mean with this phrase? Why did he use such unconventional terminology to describe this particular song? And does "Not a Second Time" indeed contain an "aeolian cadence"? These questions are regularly raised in journalistic and academic discussions about the Beatles, although the answers that are provided strongly diverge and, as I will argue in this article, are not fully satisfactory.

In this article, I will reconsider some of these questions about Lennon's aeolian cadence and also raise a few new ones. In what follows, in the first section I reconsider the debates about Mann's identification of an aeolian cadence in "Not a Second Time." After this discussion, I continue with an analysis of "Not a Second Time" and offer an alternative interpretation of its famous cadence. Underlying my analysis is the question of how to interpret a popular love song, especially with respect to the interplay between music and lyrics, and how traditional musicological formalism might fail to take account of its potential meanings. In the third section of this article, I briefly return to Mann's comparison between "Not a Second Time" and Mahler's Das Lied von der Erde, and I will raise the question whether perhaps Mann was discussing a different song by the Beatles but confused its title. But first, I outline how the aeolian cadence has been explained.

\section{Explaining the Aeolian Cadence}

In the Playboy interview from 1980, Sheff asked Lennon whether the music of the Beatles was not "at least more intelligent" in comparison to contemporary groups (Golson 78). It is in response to this question that Lennon referred to Mann's 1963 review and the aeolian cadence, as quoted above. Lennon's response prompted Sheff to wonder and ask: "Did you put aeolian cadences in 'It Won't Be Long' [sic]?” (78, emphasis in original). Although Mann actually identified an aeolian cadence in a different song, this might be irrelevant, since Lennon and Sheff were probably unaware of what constitutes such a cadence and were discussing the term rather than its meaning. Indeed, after Sheff asked Lennon whether he put aeolian cadences in "It Won't Be Long," Lennon admitted: “To this day I don't have any idea what they are. They sound like exotic birds" (78, emphasis in original).

At first glance, Lennon's response seems to illustrate a divide between, on the one hand, popular musicians and journalists, and, on the other hand, musicologists. In his short article, Mann strongly relies on musicological jargon, probably incomprehensible to most of the readers of The Times, including Lennon, of which the "aeolian cadence" is just one example. In addition to this cadence, Mann also identified "chains of pandiatonic clusters" in "This Boy" (although he names the song "That Boy"), "flat submediant key switches" in an unnamed tune, and mediant key switches in "I Want to Hold Your Hand." In contrast to these phrases, however, the term "aeolian cadence" was unheard-of even within the traditional musicological lexicon. By using this term, Mann distinguished himself not only from most readers of The Times but also from conventional academic terminology. ${ }^{3}$

As Lennon admitted in the Playboy interview, he did not have any idea what an aeolian cadence is. What complicates the situation is that Mann referred to an aeolian cadence at the end of "Not a Second Time," but the song closes with a fadeout that 
repeats Lennon's hook "not a second time" several times on a rather static alternation between the tonic $\mathrm{G}$ major and its submediant $\mathrm{E}$ minor. Because of the absence of a cadence in the fadeout, Mann probably referred to the end of the refrain, which in contrast to the coda does close with a cadence on a Bm-D7-Em chord progression that is, on iii-V7-vi in G major. This progression, moving from a dominant seventh chord to the relative minor instead of the expected tonic, is usually designated as a "deceptive cadence," yet Mann chose to invoke the aeolian mode. This term understandably puzzled many readers of The Times, including Lennon, who by recalling exotic birds jokingly misapprehended it for biological nomenclature. But why did Mann describe this cadence as "aeolian" instead of "deceptive"? The different answers that are provided to this question can generally be categorized along two lines of reasoning. The first focuses on the cultural distinction of the Beatles, and the second seeks an explanation in music theory. In this section I will discuss both of these explanations.

The first argument regarding cultural distinction is also invoked by Lennon himself. In an interview with Rolling Stone magazine, conducted by Jann Wenner in December 1970, shortly after the Beatles' breakup, Lennon commented on Mann's use of terminology in some detail. Similar to the Playboy interview ten years later, Lennon discussed the impact of Mann's review in the early stages of the Beatles' success, specifically with respect to their intellectual reception. As Lennon explained:

There is a guy in England, William Mann, who was the first intellectual who reviewed the Beatles in the Times and got people talking about us in that intellectual way. He wrote about Aeolian Cadences and all sorts of musical terms, and he is a bullshitter. But he made us credible with intellectuals. He wrote about Paul's last album [McCartney (April 1970)] as if it were written by Beethoven or something. He's still writing the same shit. But it did us a lot of good in that way, because people in all the middle classes and intellectuals were all going "Oooh." (Wenner 39)

From this perspective, Mann's terminology serves what Bernard Gendron calls the "cultural accreditation" of the Beatles (161-224). With this concept Gendron refers to the Beatles' acquisition of aesthetic distinction, as recognized by leading cultural authorities such as Mann. Indeed, Gendron specifically relates Mann's use of the term "aeolian" to the cultural accreditation of the Beatles. He explains:

In using the term "Aeolian," Mann was alluding to the presence of medieval modal scales in the Beatles' music, though the Aeolian itself corresponds to the standard minor scale of Western classical music. This jargon, obviously foreign to any "Beatlemaniac" or for that matter to most readers of the Times, was meant to evoke how Lennon-McCartney, beneath the surface simplicity of their music, were not only transgressing the harmonic bounds of popular music in a modernist way, but harkening back to preclassical European music before the diatonic system took hold. (165)

I will return to the question of modality in "Not a Second Time" below, but regardless of the credibility of Gendron's suggestion concerning medieval modes, his main argument remains valid, since the academic jargon could indeed support Mann's claim that the Beatles' music is more sophisticated than most readers of The Times might have assumed. Musicological terminology, or more generally incomprehensible jargon, could have functioned to authorize Mann as a specialist who was capable of listening through the surface simplicity of the Beatles' music to uncover its complexity. According to this 
line of reasoning, Mann would have used jargon to claim authority and to underline his argument about the Beatles' ingenuity.

This relation between musicological jargon and the invoked authority is clearly illustrated by what, to my knowledge, is the only academic publication to date that is specifically devoted to an in-depth study of Mann's 1963 review. In 1999, Michael Bach published a short German article that offers a relatively detailed examination of Mann's analysis of the Beatles' early records. In his article, Bach praises Mann for being the first musicologist to attempt a description of popular music through academic terminology. ${ }^{4}$ According to Bach, Mann recognized that popular music possesses a raison d'être equal to that of "serious music," which enabled him to analyze the Beatles' music with unprejudiced observation and empathy. ${ }^{5}$ Bach thus implies that Mann's use of musicological terminology grants his analysis an objective credibility, especially because he employed jargon that is usually reserved for serious music. Bach suggests that, because Mann describes the Beatles in terms of European classical music, his findings are unprejudiced (vorurteilsfrei), thereby neatly consolidating academic jargon with objectivity and authority.

Mann's use of jargon can certainly be explained as an attempt to claim authority, as suggested by Lennon, Gendron, and Bach; however, this does not clarify why he described Lennon's cadence in "Not a Second Time" as "aeolian.” Mann's observations pertaining to pandiatonic clusters and flat submediant key switches might have granted him some credibility among readers of The Times, but why did he deem it necessary to use this unconventional terminology? If Mann meant to claim authority, why did he not adhere to the established musicological lexicon, specialized as it is? If Mann was primarily concerned with the cultural accreditation of the Beatles, designating the cadence as "deceptive" would suffice to this end, especially in combination with a comparison to Mahler's Das Lied von der Erde. In short, the attempt at the Beatles' cultural accreditation can explain Mann's use of academic jargon in general, but not his invention of an "aeolian cadence" in particular.

The second explanation for Mann's use of this particular phrase is grounded in a musical explanation, and this line of reasoning has gained some credibility among scholars specialized in the Beatles. This interpretation is elaborated in most detail in The Songwriting Secrets of the Beatles by Dominic Pedler, who appropriately titled his chapter about "Not a Second Time" as "Exotic Birds and the Great Aeolian Cadence Mystery" (122-49). Regarding the "aeolian cadence," Pedler observes that "Dozens of books [...] pay tribute to The Times passage yet few define the musical techniques at work or attempt to explain why they 'work' - much less question the high-falutin' connections made" (124). Pedler notes that most musicologists would designate the chord progression in the refrain of "Not a Second Time" as a deceptive or interrupted cadence, because with this progression "we are literally 'deceived by the vi"' (129). This harmonic move is, in Pedler's words, "perhaps the flagship of the "Violation Of Expectations"” (129), which makes us "sit up and listen as if jolted from our slumbers" (131). However, Pedler reasonably wonders, "if the terms 'Interrupted' and 'Deceptive' cadences are so widely accepted in the classical community," then why does Mann “bring 'Aeolian' into the equation?” (132). In answer to this question, Pedler offers a musical explanation for Mann’s terminology:

Mann must implicitly have regarded Lennon's striking change as being not just to an E minor chord - but also to the key of E minor itself, however fleetingly - indeed, for just those two bars before the key of $\mathrm{G}$ major is re-established in subsequent verses and the 
coda. This may be a controversial explanation, but it seems the only likely one. (133, emphasis in original)

Pedler's interpretation of Mann's famous phrase is supported by Allan Moore, who is quoted by Pedler at length from personal correspondence:

The only way that we can make sense of Mann's use of the word "Aeolian" in "Not A Second Time" is to view that D7-Em as an "Aeolian seven-to-one", with the [b]VII acting as an "effective V" taking us powerfully to Em as a temporary tonic. In this sense Mann would argue that it is not the same thing as a "V-vi" Interrupted or Deceptive cadence because - at that precise point in the song - the role of the E minor as a "vi" is being questioned and is veering towards tonic status. (Moore quoted in Pedler 137)

This explanation, according to which the $\mathrm{E}$ minor chord becomes the tonal center rather than a deception of $\mathrm{G}$ major, is also briefly alluded to by Michael $\mathrm{Bach}^{6}$ as well as Walter Everett, who argues that the "priority of G in 'Not a Second Time' disappears in the refrain [...], which ends with a modal 'Aeolian' V (The Beatles as Musicians 193). ${ }^{7}$ In Everyday Tonality, Philip Tagg also mentions "Not a Second Time" as an example of an aeolian bVII-i cadence, and similar to Pedler he concludes that “Times critic William Mann's qualification of this Beatles cadence as aeolian may have caused the young Lennon understandable mirth but it is quite accurate" (Tagg, Everyday Tonality II 433).

If Bm-D7-Em is heard as a v-bVII-i cadence, this may be interpreted as "aeolian" because the natural minor or aeolian scale lacks a leading tone to the tonic. An aeolian progression is consequently characterized by the absence of a dominant major chord and its strong forward-directed tension and resolution, and instead it usually comprises two successive root movements upwards by a whole step according to bVI-bVII-i (or $b$ VI-bVII-I) with idiomatic parallel fifths and octaves (see Biamonte 101-04). The tonal material of rock music has frequently been discussed in these terms since Alf Björnberg's essay "On Aeolian Harmony in Contemporary Popular Music," first published in $1989,{ }^{8}$ and this discussion relates to the compelling argument that the classical terminology that derives from functional harmony is not always suitable for the analysis of rock music, which often relies on modal rather than tonal progressions (Everett, "Making Sense"; Tagg, "Troubles"; Moore, Song Means 69-76). From the early Beatles repertoire, the bVI-bVII-I cadence at the end of the refrain in "P.S. I Love You" is sometimes mentioned as exemplary of an aeolian progression (see Pedler 229; Everett, The Foundations of Rock 260; Tagg, Everyday Tonality II 285), although "Not a Second Time" is not. If Mann heard the Bm-D7-Em cadence in "Not a Second Time" as a brief allusion to $\mathrm{E}$ aeolian instead of a deception of $\mathrm{G}$ major, this is indeed a plausible explanation for why he considered the established musicological lexicon to be insufficient. Yet an aeolian progression is usually understood as comprising two successive root movements upwards by a whole step, such as in "P.S. I Love You," whereas in "Not a Second Time" Mann allegedly heard a bVII-i subtonic cadence, with the seventh scale degree acting as a substitute for the fifth. The only "aeolian" aspect of this cadence would then be the absence of an ascending leading tone to E, although this does not actually support a hearing of $\mathrm{E}$ as the temporary tonal center in the G-major context of this song. Nevertheless, more significant is that Mann seems to have observed that the chords in "Not a Second Time" do not strictly adhere to functional harmony and that 
instead the tonal center is somewhat ambiguous. At least in that respect his terminology was quite accurate indeed.

In addition to the arguments related to the cultural accreditation of the Beatles and their use of modal harmonies, a third possible explanation for Mann's terminology, and one that is not evoked by these commentators, is perhaps more pragmatic in kind. Instead of seeking the explanation in music theory or cultural distinction, as these critics do, Mann's motivation to coin the phrase "aeolian cadence" might simply be a matter of rhetoric. After all, Mann's claim about "Not a Second Time" is that the cadence sounds "so natural"; designating it as "deceptive" or "interrupted" would have undermined his central argument. This interpretation does not exclude Mann's possible interests in both cultural distinction and music theory - and, indeed, Mann's claim that the cadence sounds "so natural" is fully compatible with the explanation that he heard E minor as a temporary tonic - but it is to argue that Mann's incitement to use an unusual and confusing phrase was rhetorical rather than cultural or musical.

As becomes clear from this brief overview of the reception history of Mann's aeolian cadence, his jargon continues to both fascinate and puzzle his readers. In the final section of this article I revisit a few questions raised by Mann's review, but before attempting to reinterpret Mann's analysis it is necessary to interpret the song that started this seemingly never-ending discussion. Notwithstanding his confusing terminology, there probably is a reason why Mann singled out this particular song as exemplary of the Beatles' harmonic escapades. In the next section I will argue that, misguided by their preoccupation with Mann's terminology, his commentators forgot to listen to Lennon.

\section{Interpreting "Not a Second Time"}

Whereas in the Playboy and Rolling Stone interviews Lennon ridiculed Mann and his terminology, as quoted above, in a different interview Lennon had a more nuanced and relatively detailed recollection of the contents of Mann's 1963 review. ${ }^{9}$ On this occasion, Lennon remembered about "Not a Second Time":

I wrote this for the second album, and it was the one that William Mann wrote about in The Times. He went on about the flat sub-mediant key switches [which do not appear in the song - see below] and the Aeolian cadence at the end being like Mahler's Song of the Earth. Really it was just chords like any other chords. That was the first time anyone had written anything like that about us. (Aldridge 105) ${ }^{10}$

Here Lennon is not confused because of the word "aeolian" but because "Not a Second Time" contains chords like any other. Indeed, a cadence to the submediant is by no means unique in the early repertoire of the Beatles. On the contrary, if Mann's purpose was to exemplify their use of the submediant, he could also have discussed, for example, "P.S. I Love You" or "Do You Want to Know a Secret," both from their first album, Please Please Me (March 1963). ${ }^{11}$ What distinguishes "Not a Second Time" from these songs, however, is that in the refrain the cadence to the relative minor is not quickly followed by a resolution to the tonic, whereas in their other songs the submediant initially delays a proper resolution but does not replace the tonic as the harmonic closure of a song's section. Probably Mann was impressed by this specific feature of 
"Not a Second Time," rather than by the chords as such, which prompted him to embrace it as exemplary for their harmonic novelties. Still, as outlined in the previous section, the musicological debate that ensued from Mann's comments is predominantly concerned with what exactly he identified and, moreover, the terminology he used to describe this harmonic progression. This preoccupation with terminology and definitions distracted most observers from a different and, as I will argue, much more interesting question: Why does Lennon end the refrain of "Not a Second Time" on E minor instead of $\mathrm{G}$ major?

Early Beatles songs frequently offer the potential to interpret harmonic progressions programmatically, especially with regard to their use of the submediant. One representative example is the song "When I Get Home," composed by Lennon for their third album, $A$ Hard Day's Night (July 1964). The narrative revolves around Lennon longing to come home, because, similar to the song "A Hard Day's Night," he has "got a girl who's waiting home for me tonight." However, already in the opening refrain of this song, the chords question the whereabouts of Lennon's "home." When he sings "I got a whole lot of things to tell her, when I get home," he begins the refrain in A major but ends - on the word "home" - in A minor. The verse that immediately follows, by contrast, is dominated by $\mathrm{C}$ major; also, in the fourth and final appearance of the refrain, the cadence closes on "home" in C major. This tonal ambiguity underlines Lennon's questionable commitment to the girl who is waiting at home. ${ }^{12}$ As the narrative unfolds, Lennon sings that when he gets "home tonight" he will "hold her tight"; however, he is only "gonna love her till the cows come home," and he will "love her more till I walk out that door again." In short, the place where the girl awaits him is, similar to the wavering tonic, only his temporary "home."

How to interpret the cadence in "Not a Second Time"? Although most commentators are primarily concerned with Mann's terminology rather than with the effect of the song's harmonies, Pedler does argue that Lennon's famous cadence is perhaps not merely of harmonic interest and that his reluctance to end the refrain on $G$ major can also be interpreted programmatically. I quote his explanatory paragraph at length:

While the Em came as a surprise, you could argue in retrospect, that the atmosphere of the song was steadily previewing this very twist. We were being "set up" all along. The bridge lyrics are certainly apprehensive, particularly as each of the first four discrete lines start unsurely on a weak beat of their respective bars. The singer could go either way in both his relationship and his musical conclusion, which we await with trepidation. But the final line seals the mood as the refrain emerges, bathed in negativity, with the first of the three cries of "No" now falling on an ominous down-beat, encouraging the F\# melody note to drop to E (rather than rise to G), a fate sealed harmonically with a minor coup de grâce. (134)

Pedler thus explains Lennon's resolution to E minor instead of $\mathrm{G}$ major with reference to the moody lyrics of the song. Lennon's narrative in "Not a Second Time" revolves around a prehistory with an unnamed girl who broke his heart, presumably because she broke up their relationship, but recently she has changed her mind and she wants to get back together again. ${ }^{13}$ As Lennon establishes in the verse: "You know you made me cry," but "now you've changed your mind." In answer to her recent change of mind, the main protagonist makes clear, however, that "I see no reason to change mine." She might reconsider her feelings for him, yet he maintains that their relationship has ended. After having outlined the current state of affairs in the verse, Lennon succinctly summarizes the situation in the refrain: "You 
hurt me then, you're back again." According to Pedler, at this point in the narrative Lennon could still go either way in both his relation and musical conclusion; he might still accept her proposal to reunite, and, depending on his decision, the refrain can conclude in either major or minor. This interpretation is questionable, however, since in the verse the protagonist has already stated that he sees no reason to change his mind. Lennon repeats his stance in the final line of the refrain, asserting emphatically: "No, no, no, not a second time." He does not want to get hurt again, and out of self-protection he definitely shuts the door to their relationship. Lennon wants closure.

This final line of the refrain - "No, no, no, not a second time" - is, according to Pedler, "bathed in negativity." The melody therefore drops in the final note (on "time") to $\mathrm{E}$ instead of $\mathrm{G}$, and harmonically the phrase closes in minor instead of the expected major. But is Lennon's closure indeed "bathed in negativity"? He had expressed his sorrow when, in the verse, he recalled how previously she had made him cry; however, considering that after his closure this is no longer going to happen to him, the lyrics in the refrain are actually not as depressing as Pedler assumes. If Lennon's final statement is interpreted as negativity, this could explain why he closes the refrain in E minor instead of $\mathrm{G}$ major, yet this interpretation does not align with the narrative of the song.

If it is not for the illustration of Lennon's sorrow, then why does the refrain end on $\mathrm{E}$ minor? In my interpretation of this song, the crux lies not in the minor quality of the final chord but in its harmonic function: that of deception. In the lyrics, Lennon asserts that he will not be hurt again - that this is not going to happen for "a second time" - yet the music suggests otherwise. Even though Lennon's lyrics claim that the two former partners will not reunite, the music fails to offer the desired closure. Harmonically, the cadence at the end of the refrain illustrates precisely what Lennon's message really is - that it is deceptive - because this drama is going to happen for a second time.

This interpretation of the aeolian cadence is supported by the song's brief coda, in which Lennon repeats his line "not a second time" three times. In this coda, the underlying harmonies alternate between $\mathrm{G}$ major and $\mathrm{E}$ minor while the song slowly fades out, instead of convincingly closing the discussion with a full cadence. In agreement with the deceptive qualities of the refrain, the music in the coda seems to imply that, although Lennon repeatedly sings "not a second time," this is probably not the end of the story. Instead, the alternation between the two chords seems to mimic Lennon's on-again, off-again relationship, fading out into an indefinite conclusion. As the music in the coda suggests, not only will it happen to Lennon for a second time, but this drama is never going to end.

To my knowledge, only one author has attributed a similar interpretation to the harmonic qualities of "Not a Second Time." Between 1989 and 2000, Alan Pollack analyzed the complete Beatles canon, consisting of 187 of their own compositions and 25 covers, and published his analysis of each song online on the The "Official" rec.music. beatles Home Page. In his brief analysis of "Not a Second Time," Pollack observes that, although the Beatles had played with a tonic-submediant ambiguity before, in this song, "seemingly for the first time, it provides a programmatic touch of pathos that belies the plain meaning of the words." He explains:

The lyrics would seem on the surface to articulate a feeling of unbendable resolve not to be taken in or fooled any more, yet the manner in which the resolute harmonies of $\mathrm{G}$ major 
repeatedly give way in the refrain sections to surprising turns toward the more mournful, disappointed key of e minor would indicate that the hero is not quite so able to follow his own best advice. In "Classical" usage, such deceptive cadences to the relative minor are typically done as a tease, after which, things are quickly put right. Our song, in contrast, allows this last minute change to hold sway, making it feel all the more ominous.

Pollack also supports his interpretation with a brief analysis of the coda, arguing that "In terms of what I've described above as 'programmatic significance,' this repeated alternation of I and vi into the fade-out would seem to just about sum up the underlying mood of the song." Although Pollack does not explicitly address what this mood precisely involves and what the consequences are for Lennon's love affair, his observation that the protagonist is unable "to follow his own best advice" seems to agree with my interpretation - that despite Lennon's apparently confident and irreversible decision not to get back together again, the music suggests that this is exactly what is going to happen.

Besides the harmonies in "Not a Second Time," some of the song's structural features also play with the question of expectation and repetition. The main structure of the song is somewhat unusual, starting with two shorts verses (AA') followed by a B-section, which contains the lyrical hook (on "not a second time") and thus sounds like a refrain rather than a bridge (see Table 1). ${ }^{14}$ This refrain is not followed by a repetition of the verse, as might be expected, but by an instrumental break that repeats the refrain, played by George Martin on the piano (B'). Initially this instrumental passage could be interpreted as Lennon simply running out of words. After all, in the lyrics Lennon clearly states that this drama with his former partner is not going to happen a second time - end of story - and Martin's piano repetition of the melody merely serves as a musical embellishment to extend the song. However, after the piano solo has, faithful to the refrain, ended on E minor, Lennon returns to where he started the song - that is, to the first verse, the second verse, and the refrain (AA'B). In short, the pattern of the second part of the song (1:05-1:51 minutes) is an exact repetition of the first part (0:00-0:46).

In contrast to the vast majority of Beatles songs, in "Not a Second Time" the lyrics do not change once the verses (AA') are repeated. Instead, Lennon sings exactly the same lines. ${ }^{15}$ Except for a few details, most notably an added melisma on "you" at the end of the first verse and a few differences in the instrumental accompaniment, the music and narrative

Table 1. Structure of "Not a Second Time".

\begin{tabular}{llcc}
\hline & \multicolumn{1}{c}{ Section } & Time & Bars \\
\hline A & Verse & 0.00 & 7 \\
A $^{\prime}$ & Verse (variant) & 0.13 & 7 \\
B & Refrain & 0.26 & 10 \\
B $^{\prime}$ & Instrumental refrain & 0.46 & 10 \\
A & Verse & 1.05 & 7 \\
A $^{\prime}$ & Verse (variant) & 1.18 & 7 \\
B & Refrain & 1.32 & 10 \\
C & Coda & 1.51 & 7 \\
\hline
\end{tabular}


have not progressed at all. This repeated structure conveys an impression of a virtually static, or rather a circular, sequence of events.

Another notable structural feature in "Not a Second Time" is its use of asymmetrical hypermeasures. Each verse is seven measures long, instead of the conventional eight (or sixteen), complemented by a refrain of ten measures. Again, this feature is by no means unique in the early repertoire of the Beatles. ${ }^{16}$ One very early example is "P.S. I Love You," the B-side of their first single, "Love Me Do" (October 1962). In "P.S. I Love You," each verse is an unusual ten measures long, because the cadence supporting the final phrase (on the hook "P.S. I love you") ends somewhat deceptively on the flat submediant rather than the tonic. This unexpected harmonic twist delays the subsequent resolution to the tonic (on the reiteration "you, you, you") for two measures, which thus results in a verse of ten measures long. As argued by Pedler, this "two-bar addendum" to the verse can be interpreted "as a subliminal musical postscript for the very words of the title," subtly aligning the musical structure with the lyrics (229, emphasis in original). Another example with asymmetrical hypermeasures is "It Won't Be Long" from the album With the Beatles, which omits one measure from the verse, resulting in fifteen (seven plus eight) instead of sixteen measures. In combination with the restless harmony and melody in this song, the omission of one measure in the verse underscores Lennon's impatience and longing as expressed in the title and lyrics of the song.

As these examples illustrate, irregular hypermeasures in the early Beatles repertoire sometimes support and accentuate central elements in a song's narrative. But how to interpret the metrical asymmetry in "Not a Second Time"? Possibly it symbolizes the emotional asymmetry between Lennon and his counterpart, as outlined in the lyrics, according to which she wants to get back together again but he refuses. However, in combination with the harmonic instability, often veering off to the submediant, and the tendency in the refrain to begin phrases on the offbeat, the asymmetrical hypermeasures in this song rather create the impression that, at least musically, Lennon is not fully confident when he closes the door to their relationship. Indeed, as Everett notes with respect to the hypermeasures in "Not a Second Time": "[A]ll of this metric confusion portrays exquisitely the emotional uncertainty of the sensitive singer, John Lennon" ("Any Time at All” 190). In other words, the metric structure of this song suggests that Lennon's words might be deceptive.

In combination with the unusual structure and asymmetrical hypermeasures, the famous cadence that ends the refrain underlines Lennon's musical uncertainty. Although in an inspired moment Mann designated this cadence as "aeolian," a close listening to Lennon reveals that we should preferably describe it as "deceptive" - not because that is what it is conventionally called with respect to functional harmony, to which this song does not fully adhere, but because, within the context of "Not a Second Time," that is precisely what it is.

\section{Mahler and "Not a Second Time"}

When William Mann in 1963 analyzed "Not a Second Time," he made three observations. First, he identified an "aeolian cadence" at the end of this song. Second, he argued that this cadence sounds "so natural." Third, he compared this progression to the end of Mahler's Das Lied von der Erde. According to Richard Taruskin, this last remark is "about the loftiest comparison a critic could make in the heyday of the Mahler revival" (318); however, he continues, the "correspondences Mann found between his favorite 
classical music and that of the Beatles were not taken seriously as a comment on the Beatles' creative sources or range, but were taken only as an inventory of the critic's own musical tastes and memory" (319). Mann's comparison between Mahler and Lennon indeed seems rather improbable and perhaps only serves the "cultural accreditation" of the Beatles. Nevertheless, the question remains: What are the musical qualities that prompted Mann to make this comparison? Is this comparison indeed only an inventory of Mann's tastes and memory, or is it also grounded in some musical resemblances? In short, does Das Lied von der Erde, similar to "Not a Second Time," also end with an "aeolian cadence"?

A few commentators have raised this question, and, as it appears, with this claim Mann also managed to puzzle his readers. For example, Pedler discusses the connection between Mahler and the Beatles, and, after having outlined the comparison in some detail, he concludes that it is a myth (146-49). He supports his conclusion with two arguments. First, the final movement of Das Lied von der Erde does not close with a cadence but with a static C major chord. Second, Mahler's ending is, in contrast to the famous cadence in "Not a Second Time," "the very antithesis of surprise" (149). Pedler does note, however, that Mahler's final $\mathrm{C}$ major is an added-sixth chord, which could be interpreted as a fusion of a major tonic and its relative minor, thereby showing some resemblance to the harmonies in "Not a Second Time." In Mahler's final chord, the added sixth in the oboe and flute does not resolve, which "has elicited some of the most colourful eulogies in the history of music criticism" (Pedler 147). Yet, despite the allusion to the relative minor, these harmonies do not constitute a progression, and Pedler therefore concludes that Mahler's ending cannot be described as an "aeolian cadence." Michael Bach has also attempted to decipher Mann's comparison between Mahler and Lennon, and he claims to have traced the aeolian cadence in Das Lied von der Erde (Bach 100-01). However, Bach implausibly locates the cadence in a somewhat unremarkable passage in bars 461-466 of Mahler's final movement, about a hundred bars before the composition actually ends. Moreover, Bach admits that, despite some harmonic resemblances in this particular passage, in other respects the music by Mahler and Lennon is hardly comparable (101). Both Pedler and Bach thus have difficulty clarifying Mann's loftiest comparison between Mahler and Lennon.

As it appears, each of Mann's three observations about "Not a Second Time" has become disputable. First, the aeolian cadence at the end of the refrain is followed by a brief coda, which somewhat confuses the particular passage that Mann is referring to. Second, Lennon's cadence does not sound "so natural" but instead comes as a "deceptive" surprise, although this obviously depends on the listener. ${ }^{17}$ Third, the musical similarity between Lennon and Mahler is far-fetched, if not nonexistent. But if Mann's brief analysis of "Not a Second Time" is replete with such disputable observations, was he really discussing this particular song? Perhaps he had a different Beatles song in mind and confused the title.

That is precisely what Lennon suggested in the Playboy interview, where he not once but twice affirmed that Mann identified an aeolian cadence in "It Won't Be Long" instead of in "Not a Second Time" (Golson 78, 152). ${ }^{18}$ Lennon's confusion becomes intelligible now that Mann's description of "Not a Second Time" appears to show very little correspondence to this song. Perhaps, then, it was not Lennon but Mann who confused the two songs. Indeed, the specific context of Mann's comments might 
indicate that he was aiming at a different kind of chord progression than what is heard in "Not a Second Time." A close reading of his observations reveals that perhaps he was not describing a cadence to the relative minor, as I have assumed, but instead to the flat submediant. To quote the relevant passage from Mann's review in its entirety:

But harmonic interest is typical of their quicker songs too, and one gets the impression that they think simultaneously of harmony and melody, so firmly are the major tonic sevenths and ninths built into their tunes, and the flat submediant key switches, so natural is the Aeolian cadence at the end of "Not a second time" (the chord progression which ends Mahler's Song of the Earth).

Those submediant switches from $\mathrm{C}$ major into A flat major, and to a lesser extent mediant ones (e.g., the octave ascent in the famous "I want to hold your hand") are a trademark of Lennon-McCartney songs [...] and show signs of becoming mannerism. ("What Songs the Beatles Sang" 4)

The sentences immediately preceding and succeeding Mann's comments about "Not a Second Time" both refer to a flat submediant key switch rather than to the relative minor. Yet with his description of "those [flat] submediant switches from $\mathrm{C}$ major into A flat major," Mann seemed to argue that this is the harmonic move which he identified in "Not a Second Time." This is also how Lennon read Mann's comments, when he remembers about this song that "[Mann] went on about the flat sub-mediant key switches and the Aeolian cadence at the end being like Mahler's Song of the Earth" (Aldridge 105). According to Lennon, Mann thus identified both the aeolian cadence and flat submediant key switches in the same song, whereas the flat submediant (E-flat major in G major) does not appear in "Not a Second Time."

It seems plausible that, as Lennon suspected, with the flat submediant key switch Mann implicitly referred to "It Won't Be Long." Harmonically this is one of their most intriguing songs, in which the flat submediant (C major in E major) figures prominently in the verses. ${ }^{19}$ Besides, in contrast to "Not a Second Time," this song does close with a cadence, where the subdominant A major chromatically resolves into the tonic E major through a number of descending dominant-seventh chords. However, there is no apparent reason to describe this chromatic motion as "aeolian." Even if Mann implicitly referred to this song when invoking the flat submediant key switches, this reference is unrelated to the cadence that he squeezed into his discussion. Lennon thus took a reasonable guess that Mann was also discussing "It Won't Be Long"; however, the aeolian cadence belongs to a different song.

Despite the improbability of his comparison, Mann's brief allusion to Mahler eventually does offer the solution to the question in which song he identified an aeolian cadence. Both in Das Lied von der Erde and in "Not a Second Time," the major tonic and the relative minor are somewhat confused, although the confusion is achieved differently. Mahler's composition ends on a static C-major tonic with an added sixth in the oboe and flute. Lennon also ends the refrain on a sixth above the tonic, but his note is supported by the harmonies of the submediant instead of the expected tonic $G$ major. ${ }^{20}$ The effects of these sonorities, however, are remarkably similar. In Das Lied von der Erde's final movement, titled "Der Abschied" (the farewell), the alto ends the text of the composition by repeatedly singing the word "ewig" (for eternity), while the orchestra slowly fades out on a C major chord. After her last reiteration of "ewig," the oboe and flute occupy the higher register and play a repeated E-G-A motive in C, which resembles the iii-V7-vi progression in "Not a Second Time" and probably forms the 
source of inspiration for Mann's comparison between Mahler and the Beatles. Upon the last repetition of this motive, the oboe and flute sustain the final $\mathrm{A}$ above the tonic $\mathrm{C}$ major. Because this added sixth does not resolve, the final sonorities seem to suggest an indefinite ending, thus supporting the eternity as emphasized in the text. If in "Not a Second Time" Lennon's farewell to his former partner is heard as deceptive, as I have argued - that is, if the music subverts a proper closure and instead suggests a neverending on-again, off-again relationship - we can finally start to hear the similarity between Das Lied von der Erde and "Not a Second Time." As Mann heard correctly, this story is never going to end.

I do not know whether my interpretation of "Not a Second Time" fully agrees with Lennon's intentions when writing this song. To my knowledge, Lennon never publicly clarified his intentions; and if he ever did there is a good chance that his explanation itself is deceptive, either because he comically fooled the journalist, perhaps because he forgot, or because he composed the song intuitively rather than intentionally. For example, when in the Playboy interview David Sheff asked Lennon to say something about "Not a Second Time," Lennon answered: "That's me trying to do something. I don't remember. [Laughs]" (Golson 172). On a different occasion, during an interview with Howard Smith in 1972, Lennon hears "Not a Second Time" on the radio in the background and remembers in more detail:

Oh, this song, I've forgotten what it's called. I wrote it. "Not a Second Time" was one of those ones that was written [about] by Thomas Mann [sic] in The Times with the Aeolian cadences - I still don't know what it means - at the end. The chords at the end are like Mahler's Fifth Symphony [sic]. All that jazz. To me, I was writing a Smokey Robinson or something at the time. But it had Aeolian cadences, and all that jazz started after that. ${ }^{21}$

Probably it is impossible to trace Lennon's intentions when writing "Not a Second Time," but what is more significant is "all that jazz" - that is, the intellectual reception of this song and of the Beatles' music more generally - starting with Mann in 1963 and still lingering in musicological debates. As I have argued, Mann's early review basically initiated two tendencies. First, it prompted an interest in the Beatles by the cultural highbrows. Lennon had ambivalent feelings about this development, noting in 1970 that Mann "is a bullshitter" but quickly added that his review "did us a lot of good in that way, because people in all the middle classes and intellectuals were all going 'Oooh"' (Wenner 39). When ten years later David Sheff asked Lennon whether "a lot of the Beatles [wasn't] at least more intelligent," he answered that they "were more intellectual, so they appealed on that level, too. But the basic appeal of the Beatles was not their intelligence. It was their music" (Golson 78). Lennon's uncomfortable distinction between intelligence and music can perhaps be interpreted as an appeal to stop talking and start listening; yet in contrast to Lennon's love affairs in "Not a Second Time" the intellectual reception of the Beatles has become irreversible.

The second tendency, closely related to the first, is that Mann tuned the ears of musicologists to the formal features of the Beatles' music, but he thereby distracted them from listening to the interplay with the words. Interestingly, in Mann's review of Sgt. Pepper's Lonely Hearts Club Band (1967), also published in The Times, he wrote that the "words of songs are as important as the music: Monteverdi, Schumann, Wolf, 
Britten have all accepted this belief to their advantage, and pop music has benefited whenever composers have done likewise" (Mann, "The Beatles Revive Hopes" 9). Specifically with respect to popular music, Simon Frith concludes his seminal essay "Why Do Songs Have Words?" (1986) with the compelling argument that love songs "give people the romantic terms in which to articulate and so experience their emotions" (102). In popular songs, according to Frith, the interplay between music and words provides the means to experience falling in love. But sometimes, such as in "Not a Second Time," it provides the means to fall in love again.

\section{Notes}

1. Mann's review is also reprinted in several collected volumes (Brackett, Pop 172-73; Braun 66-68; Thomson and Gutman 27-29).

2. The only contemporary source of this statement that I have been able to trace quotes the Queen Mother saying: "[they are] so young, fresh, and vital" ("Beatlemania" 104). At the Royal Variety Show, Lennon famously introduced "Twist and Shout" with his request to the audience: "For our last number, I'd like to ask your help. Would the people in the cheapest seats clap your hands; and the rest of you - if you'd just rattle your jewelery" (see the video recording "The Beatles-Twist and Shout" (https://www.youtube.com/watch?v= HS02tKCSGtg)). Despite Lennon's request, however, according to a report in the New York Times Magazine the Queen Mother "was seen clapping on the off-beat" (Lewis 126).

3. The phrase was more common in Germanic musicology as an "äolischen Kadenz." For example, Hans Joachim Moser uses this term in his Allgemeine Musiklehre (1940) to refer to a cadence formed by the tonal material of the natural minor (or "aeolian") scale, which is characterized by the absence of a major sixth and seventh and consequently contains minor subdominant and dominant chords (71). According to Moser, a "i-v-iv-i" chord progression is "a true aeolian cadence" ("einer echt äolischen Kadenz"), with descending instead of ascending leading tones (71). Also see the entry on "Moll" ("minor scale") in Moser's Musik Lexikon for his definition of an "äolischen Kadenz" (792-94). It seems likely that Mann borrowed the term from Germany; however, the particular type of cadence that Moser describes does not appear in "Not a Second Time."

4. “Zusammenfassend betrachtet zeigt sich Manns Rezension vom Dezember 1963 als erster Versuch eines Musikwissenschaftlers, ein popmusikalisches Phänomen mittels wissenschaftlicher Terminologie zu beschreiben" (Bach 102).

5. "Seinen Erkenntnissen zur Musik der Beatles liegt offensichtlich ein Selbstverständnis darüber zugrunde, da $\beta$ populäre Musik eine der E-Musik ebenbürtige Daseinsberechtigung besitzt, und so geht Mann an seinen Betrachtungsgegenstand mit vorurteilsfreier Beobachtungsgabe und Einfühlungsvermögen heran" (102). Bach's reference to E-Musik, or ernste Musik ("serious music"), is meant to distinguish classical music from U-Musik, or Unterhaltungsmusik ("entertainment music").

6. "Durch die Akkordprogression a-Moll - h-Moll - D-Dur, also Subdominante, Dominante und Dominantparallele einer äolischen Kadenz, wird e-Moll für kurze Zeit zum tonalen Zentrum" (Bach 100).

7. According to Everett, however, Mann identified the aeolian cadence in the coda rather than in the refrain: "In fact, this alternation of I and VI, with which the coda fades out, was one object of praise in William Mann's notable end-of-year review of the Beatles as Britain's best composers ('so natural is the Aeolian cadence at the end of "Not a Second Time"')" (The Beatles as Musicians 192).

8. For discussions about aeolian progressions in rock music, see in particular Moore ("The So-Called 'Flattened Seventh' in Rock"); Everett (The Foundations of Rock 247-61); 
Biamonte (101-04); and Tagg (Everyday Tonality II 382-86). Björnberg's essay is reprinted in Moore's Critical Essays in Popular Musicology (275-82).

9. Lennon discussed Mann's review and its impact on the intellectual reception of the Beatles in at least five interviews (Aldridge 105; "Lennon-McCartney Songalog: Who Wrote What"; Burger 259; Golson 78, 152; Wenner 39).

10. Although to my knowledge this quote was first published in 1971, it is unclear when Lennon spoke these words. This passage is also quoted by Miles and Marchbank (78) and Badman (72).

11. The submediant also figures prominently in each of their first three number-one hit singles - "From Me to You" (April 1963), "She Loves You" (August 1963), and "I Want to Hold Your Hand" (November 1963) - although in these songs the chord does not function in a cadence.

12. See Pedler (142-43) for a similar interpretation of the tonal qualities in this song.

13. This is admittedly a heteronormative interpretation of the lyrics; actually, the gender of Lennon's former partner remains unclear. In his controversial biography, The Lives of John Lennon, Albert Goldman exploits the rumor about Lennon's homosexual affair with Brian Epstein during their holiday trip to Barcelona in April 1963, five months prior to the recording session of "Not a Second Time" (Goldman 139-41, 147-48; also see Shotton and Schaffner 73; Graff and Durchholz 78-81). This rumor about Lennon's affair with Epstein forms the basis for the film The Hours and Times (1991), directed by Christopher Münch. In the Playboy interview Lennon tells David Sheff: "I was on holiday with Brian Epstein in Spain, where the rumors went around that he and I were having a love affair. Well, it was almost a love affair, but not quite. It was never consummated. But it was a pretty intense relationship" (Golson 151).

14. On form in early Beatles songs, see Covach; Everett, The Beatles as Musicians 48-51; Pedler 730-37.

15. Another early Beatles song without variable lyrics in the verses is "Love Me Do."

16. See Everett ("Any Time at All") for an overview of the Beatles' use of asymmetrical hypermeasures.

17. According to Pedler, the cadence makes us "sit up and listen as if jolted from our slumbers" (131). Pollack, by contrast, notes that the tonal ambiguity throughout the refrain "helps smooth over the deceptive cadence and makes it the more believable when it happens" (Pollack). Moreover, as argued by Everett (The Beatles as Musicians 193), the downward movement of Lennon's vocal line prepares the listener for a melodic cadence in $\mathrm{E}$, when the $\mathrm{F} \#$ drops to $\mathrm{E}$ rather than moving up to $\mathrm{G}$. In that sense, the cadence does indeed sound natural.

18. Lennon had previously confused the two songs in an interview with Hit Parader magazine (April 1972). When asked about "It Won't Be Long," Lennon answered: "I wrote this on the second album. It was the song with the so-called Aeolian cadences, the same as in the Mahler symphony, at the end. I don't know what the hell it is about" ("Lennon-McCartney Songalog: Who Wrote What").

19. Both Pedler $(124,200)$ and Bach (98) suggest that with the "flat submediant key switch" Mann probably referred to "It Won't Be Long." However, this does not explain why Mann specified the submediant key switch "from C major into A flat major." Other early Beatles songs in which the flat submediant appears are "P.S. I Love You," "I Saw Her Standing There," "Do You Want to Know a Secret," and "Till There Was You" (see Pedler 199-204), but to my knowledge none of the early Beatles songs switch specifically between $\mathrm{C}$ major and A-flat major.

20. In this respect, Mahler's ending actually more closely resembles the final chord of "She Loves You" (August 1963).

21. This interview has recently been transcribed and published by Jeff Burger (259). I have slightly modified his transcription. 


\section{Disclosure statement}

No potential conflict of interest was reported by the author.

\section{Works cited}

Aldridge, Alan, ed. The Beatles Illustrated Lyrics 2. London: BPC Publishing, 1971.

Bach, Michael. "'What Songs the Beatles Sang...': Der Musikkritiker William Mann Und Seine Erste Rezension Eines Popmusikalischen Phänomens.” Jahrbuch Für Volksliedforschung 44 (1999): 95-104. doi:10.2307/848858

Badman, Keith. The Beatles off the Record. London: Omnibus Press, 2000.

"Beatlemania." Newsweek 18 Nov. 1963: 104.

Biamonte, Nicole. "Triadic Modal and Pentatonic Patterns in Rock Music." Music Theory Spectrum 32.2 (2010): 95-110. doi:10.1525/mts.2010.32.2.95

Björnberg, Alf. "On Aeolian Harmony in Contemporary Popular Music." Göteborg, Sweden: IASPM - Nordic Branch Working Papers, 1989. 1-8.

Björnberg, Alf. "On Aeolian Harmony in Contemporary Popular Music." Critical Essays in Popular Musicology. Ed. Allan F. Moore. Aldershot, UK: Ashgate, 2007. 275-82.

Brackett, David. "The Beatles, the 'British Invasion,' and Cultural Respectability.” The Pop, Rock, and Soul Reader: Histories and Debates. Ed. David Brackett. Oxford, UK: Oxford University Press, 2005. 170-74.

Brackett, David ed. The Pop, Rock, and Soul Reader: Histories and Debates. Oxford, UK: Oxford University Press, 2005.

Braun, Michael. Love Me Do: The Beatles' Progress. Harmondsworth, UK: Penguin Books, 1964.

Burger, Jeff. Lennon on Lennon: Conversations with John Lennon. Chicago: Chicago Review Press, 2017.

Covach, John. "From 'Craft' to 'Art': Formal Structures in the Music of the Beatles." Reading the Beatles: Cultural Studies, Literary Criticism, and the Fab Four. Ed. Kenneth Womack and Todd Davis. Albany: State University of New York Press, 2006. 37-53.

Everett, Walter. The Beatles as Musicians: The Quarry Men through Rubber Soul. Oxford, UK: Oxford University Press, 2001.

Everett, Walter. "Making Sense of Rock's Tonal Systems." Music Theory Online 10.4 (2004). Web.

Everett, Walter. "Any Time at All: The Beatles' Free Phrase Rhythms." The Cambridge Companion to the Beatles. Ed. Kenneth Womack. Cambridge, UK: Cambridge University Press, 2006. 37-53.

Everett, Walter. The Foundations of Rock: From "Blue Suede Shoes" to "Suite: Judy Blue Eyes." Oxford, UK: Oxford University Press, 2009.

Frith, Simon. "Why Do Songs Have Words?" Sociological Review 34.S1 (1986): 77-106. doi:10.1111/j.1467-954X.1986.tb03315.x

Gendron, Bernard. Between Montmartre and the Mudd Club: Popular Music and the AvantGarde. Chicago: University of Chicago Press, 2002.

Goldman, Albert. The Lives of John Lennon. London: Bantam Press, 1988.

Golson, Barry ed. The Playboy Interview with John Lennon and Yoko Ono. New York: Playboy Press, 1981.

Graff, Gary, and Daniel Durchholz. Rock 'N' Roll Myths: The True Stories behind the Most Infamous Legends. Minneapolis, MN: Voyageur Press, 2012.

Harry, Bill. The Beatles Encyclopedia. London: Virgin Publishing, 2000.

"Lennon-McCartney Songalog: Who Wrote What." Hit Parader Apr. 1972: 15-17. Web. 18 Sept. 2017. Lewis, Frederick. "Britons Succumb to 'Beatlemania." New York Times Magazine 1 Dec. 1963: 126. Mann, William. "What Songs the Beatles Sang." The Times 27 Dec. 1963: 4.

Mann, William. "The Beatles Revive Hopes of Progress in Pop Music." The Times 29 May 1967: 9. Mellers, Wilfred. Twilight of the Gods: The Beatles in Retrospect. London: Faber \& Faber, 1973. 
Miles, Barry, and Pearce Marchbank eds. Beatles in Their Own Words. London: Omnibus Press, 1978. Moore, Allan F. “The So-Called 'Flattened Seventh' in Rock.” Popular Music 14.2 (1995): 185-201. doi:10.1017/S0261143000007431

Moore, Allan F. ed. Critical Essays in Popular Musicology. Aldershot, UK: Ashgate, 2007.

Moore, Allan F. Song Means: Analysing and Interpreting Recorded Popular Song. Farnham, UK: Ashgate, 2012.

Moser, Hans Joachim. Allgemeine Musiklehre. Berlin: Walter de Gruyter \& Co, 1940.

Moser, Hans Joachim. Musik Lexikon. Hamburg: Musikverlag Hans Sikorski, 1955.

Pedler, Dominic. The Songwriting Secrets of the Beatles. London: Omnibus Press, 2003.

Pollack, Alan. "Notes on "Not a Second Time." The "Official" rec.music.beatles Home Page. 1991. Web. 18 Sept. 2017.

Schaffner, Nicholas. The Beatles Forever. New York: McGraw-Hill, 1978.

Shotton, Pete, and Nicholas Schaffner. John Lennon: In My Life. New York: Stein and Day, 1983.

Tagg, Philip. “Troubles with Tonal Terminology." 2011. https://www.tagg.org/xpdfs/ Aharonian2011.pdf. Web.

Tagg, Philip. Everyday Tonality II. New York and Huddersfield, UK: Mass Media Music Scholars' Press, 2014. Web.

Taruskin, Richard. The Oxford History of Western Music: Music in the Late Twentieth Century. Oxford, UK: Oxford University Press, 2010.

Thomson, Elizabeth, and David Gutman eds. The Lennon Companion: Twenty-Five Years of Comment. London: Macmillan Press, 1987.

Wenner, Jann. “The Rolling Stone Interview: John Lennon.” Rolling Stone 21 Jan (1971): 32-42.

\section{Songs and Recordings}

"Do You Want to Know a Secret." Written by John Lennon and Paul McCartney. Recorded by the Beatles. Please Please Me. UK. Parlophone, 1963.

"From Me to You." Written by John Lennon and Paul McCartney. Recorded by the Beatles. "From Me to You"/“Thank You Girl." UK. Parlophone, 1963.

"A Hard Day's Night." Written by John Lennon and Paul McCartney. Recorded by the Beatles. A Hard Day's Night. UK. Parlophone, 1964.

"I Saw Her Standing There." Written by John Lennon and Paul McCartney. Recorded by the Beatles. Please Please Me. UK. Parlophone, 1963.

"I Want to Hold Your Hand." Written by John Lennon and Paul McCartney. Recorded by the Beatles. "I Want to Hold Your Hand"/“This Boy." UK. Parlophone, 1963.

"It Won't Be Long." Written by John Lennon and Paul McCartney. Recorded by the Beatles. With the Beatles. UK. Parlophone, 1963.

"Love Me Do." Written by John Lennon and Paul McCartney. Recorded by the Beatles. "Love Me Do"/“P.S. I Love You." UK. Parlophone, 1962.

"Not a Second Time." Written by John Lennon and Paul McCartney. Recorded by the Beatles. With the Beatles. UK. Parlophone, 1963.

"P.S. I Love You." Written by John Lennon and Paul McCartney. Recorded by the Beatles. "Love Me Do"/“P.S. I Love You.” UK. Parlophone, 1962.

"She Loves You." Written by John Lennon and Paul McCartney. Recorded by the Beatles. "She Loves You"/“I'll Get You.” UK. Parlophone, 1963.

"This Boy." Written by John Lennon and Paul McCartney. Recorded by the Beatles. "I Want to Hold Your Hand"/“This Boy.” UK. Parlophone, 1963. 
“Till There Was You." Written by Meredith Willson. Recorded by the Beatles. With the Beatles. UK. Parlophone, 1963.

"Twist and Shout." Written by Phil Medley and Bert Russell (I.E., Bert Berns). Recorded by the Beatles. Please Please Me. UK. Parlophone, 1963.

"When I Get Home." Written by John Lennon and Paul McCartney. Recorded by the Beatles. A Hard Day's Night. UK. Parlophone, 1964. 